\title{
Municipalities' Policy on Innovation and Market Introduction in Sustainable Energy: A Focus on Local Young Technology Firms
}

\author{
Marina Van Geenhuizen *(D) and Razieh Nejabat
}

check for updates

Citation: Van Geenhuizen, M.; Nejabat, R. Municipalities' Policy on Innovation and Market Introduction in Sustainable Energy: A Focus on Local Young Technology Firms. Energies 2021, 14, 1094. https:// doi.org/10.3390/en14041094

Academic Editors: Russell McKenna and Stefan Petrović

Received: 5 January 2021

Accepted: 14 February 2021

Published: 19 February 2021

Publisher's Note: MDPI stays neutral with regard to jurisdictional claims in published maps and institutional affiliations.

Copyright: (c) 2021 by the authors. Licensee MDPI, Basel, Switzerland. This article is an open access article distributed under the terms and conditions of the Creative Commons Attribution (CC BY) license (https:/ / creativecommons.org/licenses/by/ $4.0 /)$.
Faculty of Technology, Policy and Management, Delft University of Technology, 2628 BX Delft, The Netherlands; r.nejabat-1@tudelft.nl

* Correspondence: m.s.vangeenhuizen@tudelft.nl

\begin{abstract}
Municipalities are increasingly involved in energy transition planning. There are, however, doubts about whether municipalities are an adequate organization and scale level for this. In this context, the article aims to picture developments of local young technology firms in bringing energy inventions to market, in particular, how municipalities have provided support to them. Such aim, in the context of energy transition, is new. Derived from study in Nordic countries and The Netherlands, two findings make a valuable contribution to literature. Firstly, a share of almost $40 \%$ of young technology firms fails in market introduction, and if reached the market, a $30 \%$ is rather late. Barriers stem from high risk-taking, late (no) collaboration, and limiting circumstances in metropolitan cities. Secondly, municipalities' initiatives appear useful in filling young technology firms' needs, but the initiatives are fragmented and miss priority. However, partnering in professional start-up organizations tends to improve the situation, indicating that the municipal level is promising in transitional change with regard to new technology. In contrast, driving energy transition through regional cluster building, includes different levels of functional interdependence, territorial scale, networking and governance, causing manifold complexity and uncertainty. Not all (large) municipalities seem able to act in a promising manner, however, much empirical research needs to be done.
\end{abstract}

Keywords: energy transition; municipalities' planning; young technology firms; market introduction

\section{Introduction}

\subsection{Increased Urgency for Municipalities' Involvement in Transitional Change}

Cities and their municipalities are faced with an increased urgency for sustainable energy transition and system innovation, e.g., given their high energy consumption (ca. twothirds of global energy demand), $\mathrm{CO}_{2}$ emissions (about 75\%) and population growth (an estimated $70 \%$ by 2050 live in cities) [1]. These shares will rise as cities grow and urban economic activity expands. To make more efficient use of the world's energy resources, increase energy security, meet global climate targets, and develop underlying technology inventions, it is essential that more cities take a leading role in the energy transition [2,3]. The longer action is delayed, the greater the chance that inefficient choices will be 'locked-in' for decades to come, preventing transition.

Many initiatives (interventions) to counteract unsustainable energy behavior of cities have originated in the post-Rio years, the late 1990s and early 2000s. Already in those years the question was posed on extents to which cities and local governments can address the challenges of climate change [4]. One line of discourse deals with the multiple spatial scales with different interpretation of sustainability, and with multiple governance levels beyond the traditional boundary of municipalities [4]. A second line of discourse and research followed close before the Paris Agreement (2015), in which cities are addressed as places of local experimentation, as critical means in climate change and regime transformation [5-7]. In this context, increasingly, the question is posed on upscaling of the 
results of experimentation [8]. One case in point, specifically emphasizing the role of local citizens, is the urban living lab, as urban sites intended for experimentation, including design, testing and learning from social and technical innovation in a real time and real life setting [9-15]. While urban living labs have received much attention in literature, young technology firms and their transitional capabilities through energy inventions, seem neglected, however, with a few exceptions [16-19]. A stronger focus on such firms would provide better understanding of municipalities' organizational and environmental quality for creation of new energy technology and adoption in the market.

Cities and municipalities tend to be different in capacity to respond to the urgency of transitional change. For example, larger (global) cities are well-positioned, due to density of human, economic, intellectual and cultural capital. Such situation has been emphasized since a long time in the concept of agglomeration economies [20-22] and partially also in the more recent approach of entrepreneurial ecosystems [23]. The last encompasses the urban (regional) environment and supportive qualities, in particular networks and institutions, as well as the entrepreneurial (risk-taking) strategy of firms. It is worth notice that smaller and specialized university cities may also play substantial roles, if they are close to places of abundant availability of renewable energy resources [24,25]. Also, being part of a specific country's knowledge economy, institutional system and entrepreneurial culture (National Innovation System, NIS), can make a difference between municipalities in local assets in transition challenges [26-30].

\subsection{Young Technology Firms, Energy Systems and Municipalities}

The study has a focus on specific start-ups that are 'fueled' with up-to-date technology developed at university: university spin-of firms. This category of start-ups is defined as established independently, with the aim to develop university inventions and bring them to market $[31,32]$. University spin-offs often receive basic local support in the first years, namely, through incubator services and accelerator programs, but some of them tend to remain vulnerable due to lack of market knowledge and management skills, short in financial capital and legitimacy $[33,34]$, making reaching the market a risky affair $[35,36]$. A part of spin-off firms, in contrast, is genuinely risk-taking and may quickly shift to local or specialized markets. Also, compared to large incumbents, such firms may be able to quickly capitalize on innovation and sustainable practices, and by smart networking they accelerate first sales and scaling-up to large segments in the market, thereby influencing transitional change considerably [37-39]. However, many constraints are mentioned in literature, specifically on scaling-up and the energy system [40-43].

Energy systems can be conceptualized as social-technical systems with emphasis on complexity and evolutionary dynamics, including 'layers' of different change dynamics and resistance to change [44-49]. The so-called regime is seen as acting as the solid structure that preserves stability in the system, derived from rules that direct and coordinate social and economic behavior in reproducing system activities. These include lock-in mechanisms, like sunk costs, vested interests, user preferences, experienced business models, etc. So-called niches are another system level [50-53], but on this level real-life learning on inventions is possible under 'sheltered' circumstances, e.g., beyond influence of the market (prices) and regulation. The experimentation in niches encompasses effectiveness of inventions, customer demand, regulation (standards), and legitimacy towards large firms, governments, etc., and if successful, such experimentation contributes to institutional changes and reducing regime resistance.

In the context of market introduction and system resistance, our focus is on strategic choices of young technology firms, and their orientation on innovativeness, pro-activeness and competitive 'aggressiveness', in particular risk-taking [54-58]. The choices include the energy technology itself, in terms of radicalness of technology (product) and newness of the market, the last because particular inventions are accepted, like wind energy, while others may face (fierce) 'resistance', e.g., hydrogen as carrier and energy source. Next, a choice is to adopt diversification (e.g., with services, or related traditional products) as 
a short-term risk-avoiding strategy, for example, aimed at raising cash in the face of the 'valley of death' [59-61]. However, strong diversification may also cause delay in market introduction of the invention. In the context of risk-taking and learning, we also use the competence-based view. This view posits that owning or gaining competence to better use resources, including identifying needs for new resources, may increase competitiveness and enhance a shorter time to market [62,63]. Size of the founding team and high education level are often mentioned in this respect, as these increase the probability of achieving diverse and rich information. However, strong diversity in information, opinions, etc. may cause emergence of fault-lines within teams, causing delay in strategic decisions [64,65]. Further, young firms may increase competences by extending the founding team with experienced marketing/business persons, by collaboration with a large firm, eventually in a niche, and by accessing first substantial investment [61]. The basic assumption we adopt, is the earlier such steps are taken, the shorter the time to market will be, though there are signs of more complicated development $[61,66]$.

Further, young firms in risky technology/markets may benefit from high-quality entrepreneurial ecosystems, as influenced by National Innovation Systems, like subsidies for specific energy R\&D, strong entrepreneurial spirit, and SMEs support programs, and by metropolitan agglomeration advantages, summarized as knowledge spillovers, nontraded local inputs and skilled labor pool. All these local assets are assumed to improve opportunity recognition, networking and dealing with institutional challenges (e.g., legal, regulatory) [67-71]. At this point, municipalities' planning enters the scene.

Municipalities are involved in energy transition through their historical and current activity as energy producers, in particular, in low populated regions in Scandinavia in local electricity and district heating, like in Sweden [72], and in windfarm activity, like in Denmark [73]. Since the early 1980s, energy conservation and efficiency came on municipalities' agenda's, with great efforts in municipal town planning and housing programs, followed in the 1990s by sustainable energy transitional change, and more recently with emphasis on urban experimentation and upscaling. Today large (global) cities are addressed as 'drivers' of transitional change in international programs and networks. The profile of 'driver' is most comprehensive, as it encompasses not only the own organization and territory, including local citizens' participation [74-76], but also multiple spatial scales, multiple stakeholders and (related) systems networking [77,78].

\subsection{Aim, Research Question and Research Design}

The extent to which municipalities' organization and scale match the needs of transitional experimentation can be questioned, due to complicated socio-technical systems relationships (e.g., [4,5]), in particular regarding young technology firms. The aim of the paper is therefore to picture past development of young technology firms in bringing energy inventions to market, in particular, how municipalities have provided support. Accordingly, we address the following research questions: (a) To what extent are local university spin-off firms able to reach the market with their invention, which time is involved, and what are the underlying factors? (b) Which entrepreneurial needs (barriers) are evident and with which initiatives are municipalities responding to such needs? (c) To what extent do these initiatives provide arguments for viewing municipalities' organization and scale as promising, thereby distinguishing between transitional change measures and acting as 'driver' of transitions?

The research design is as follows: We first empirically investigate time to market introduction among young university spin-off firms that are involved in energy inventions, and factors that underlie differences in this time. We use a longitudinal database of 106 firms and apply Cox regression analysis in identifying several needs and barriers in quick market introduction. Next, the needs and barriers inform a discussion of initiatives that municipalities (may) take in providing support to young technology firms, which draws on desk research and interviews. This discussion serves to evaluate in a preliminary 
way to what extent municipalities are the right scale and organization to address the challenges of transitional change, using a set of initiatives and comprehensive cluster policy.

In Section 2, we address methodology aspects of the analysis of firms' market introduction. Section 3 presents the results on firms' time to market, including underlying factors, and the results of exploration of municipalities' initiatives in response to young firms' needs. Comprehensive 'driving' of energy transition is also addressed. The article closes with Section 4 providing a summary and discussion, as well as limitations of the current study and future research directions.

\section{Materials and Methods}

\subsection{Database, Measurement and Descriptive Statistics}

We use data on spin-off firms (a total of 106) in northwest Europe, established since 1998 [19]. The choice of countries-Denmark, Finland and Sweden-is motivated by favorable small firm and innovation conditions that allowed us to observe market introduction and longer term surviving of young technology firms, while Norway and The Netherlands are included as these have faced some less favorable conditions in (some) past years [28-30]. In The Netherlands, for example, the large consumption of natural gas acts as a country-specific barrier to experimentation. Further, the cities where the firms were established, include core metropolitan areas like Copenhagen in Denmark and North Randstad (e.g., Amsterdam) in The Netherlands, and also larger and smaller cities at a distance from these areas, like Trondheim (Norway) and Lappeenranta (Finland). The cities are listed per country in Appendix A. The size of the sample was the outcome of a search process using universities' lists of spin-off firms, national reports on sustainable energy research/application and sector journals, like Nordic Green. We may have overlooked some spin-offs that failed before start of the data collection, but some simulation outcomes indicated no need for concern [19]. Accordingly, we may claim that the 106 firms are to a large extent representative for university spin-off firms involved in energy inventions established since 1998.

To collect firm data, like year of market introduction, risk-taking strategies, competences, and location, we used a multi-source data collection method, encompassing in-depth interviews of firm founders and telephone enquiry, supplemented with deskresearch, firms' websites, including those referring to statements of investment consortia and acquiring firms. Data-collection (in fact, 'reconstruction' of the firms' past development) started in 2015 and lasted till late 2018 and was aimed at producing firm data ranging from 1998, as earliest year of firm foundation, to 2018. This long time-period served a longitudinal approach in which time of market introduction could be analyzed on the firm level, by using data on foundation, strategic choices and competences, etc.

We now briefly summarize characteristics of the sample (see, Appendix B for measurement and scores, and Appendix C for correlation matrix). Market introduction was achieved by $61 \%$ of the sampled firms, but $39 \%$ failed in market introduction. On average, the market was reached after four years. With regard to underlying strategic choice, the sample shows manufacturing-oriented activity among $75 \%$ of firms, radical invention among $41 \%$, and new and emerging markets for $19 \%$ and $56 \%$ respectively (all seen as relatively strong risk-taking). Diversification as risk-reducing strategy is undertaken by about half of the spin-offs (52\%). With regard to competences, founding team size is on average slightly more than two persons, with a maximum size of six persons. The education level of $\mathrm{PhD}$ is present among $72 \%$ of the sampled firms, and pre-start business experience is owned by $48 \%$. Joining of a market/business team member is undertaken by $24 \%$, as many firms had such team member already at start (47\%). The share of firms that have remained all years without such member, is $29 \%$. Regarding first substantial investment capital, a time-period of less than five years holds true for $41 \%$ and five years or later for a small minority $(16 \%)$, while $43 \%$ never faced such investment. Concerning first collaboration/partnership with an important actor (often a large firm) the data enabled to measure time more accurately: the average time was close to 3.5 years after start, but 
$22 \%$ never developed such collaboration. And finally, with regard to the entrepreneurial ecosystem indicators-quality of NIS and metropolitan character of location-there is a small majority of the sampled firms in Sweden, Finland and Denmark (53\%) as well as in core metropolitan and adjacent area (57\%).

\subsection{Modelling}

More than half of all firms (61\%) have reached market introduction, measured as 'reported first sales', while 39\% failed to do so (Table 1). Among the ones that reached the market, 69\% did that at early age (five years or younger).

Table 1. Age of Market Introduction.

\begin{tabular}{ccccc}
\hline $\begin{array}{c}\text { Market } \\
\text { Introduction }\end{array}$ & $\begin{array}{c}\text { Introduction at } \\
\text { Early Age } \\
(\mathbf{0 - 5 )}\end{array}$ & $\begin{array}{c}\text { Later } \\
\text { Introduction } \\
\text { (Age > 5) }\end{array}$ & $\begin{array}{c}\text { Failure in Market } \\
\text { Introduction }\end{array}$ & Totals \\
\hline $65(61 \%)$ & $45(42 \%)$ & $20(18 \%)$ & $41(39 \%)$ & $106(100 \%)$ \\
\hline $65(100 \%)$ & $45(69 \%)$ & $20(31 \%)$ & - & - \\
\hline
\end{tabular}

To explore market introduction as an 'event' in firms' life-time, we applied Cox proportional hazard model, a semi-parametric method which calculates probabilities of a certain event. In Cox proportional hazard method it is assumed that the covariates have a multiplicative effect on a basic hazard function. A specification of the model is given in Appendix D.1 The method has often been used in analysis of longitudinal censored data (in our case, end of the observation period in 2018) [79-81].

We checked multi-collinearity of independent variables with the result that no strong collinearity was found. Variation inflation factors (VIF) were below 2.00, with mean VIF at 1.38. Other tests confirmed that our data set also meets specific assumptions of Cox regression analysis (Appendix D.2). Cox estimation outcomes provide the hazard ratio (HR) for each factor in the models which should read as follows. If a hazard ratio of a factor is close to 1 , than that factor does not affect time to market. If a hazard ratio is substantially less than 1, than market introduction takes a longer time. Conversely, if substantially greater than 1, market introduction takes a shorter time.

\section{Results}

\subsection{Time of Market Introduction and Underlying Factors}

On average, market introduction is at the age of 4.4 years, however, there is some variation as indicated by the standard deviation (3.2) and maximum age of 14 years (Appendix B). Application of Cox regression in the exploration of underlying factors, provides the following understandings, model by model (model 1-3) (Table 2):

(1) Strategic choice indicates that involvement in a radical technology, a new market and manufacturing-oriented activity, increases the probability of a longer time to market. The outcomes of all three indicators are also statistically significant. The last strategic choice factor, business diversification, tends not to affect time to market, as it may have two sides (as assumed), namely, risk-reduction through raising additional turnover and loss of focus causing delay.

(2) Competences/resources results indicate no specific influence on time to market introduction for three indicators, given values close to 1, namely, size of founding team, pre-start business experience, and time to first substantial investment. Two indicators show significant results. Firstly, presence of higher education among founders (PhD), which tends to shorten time to market introduction, most probably due to benefits from rich or advanced information. Secondly, longer time to first collaboration with a large partner tends to delay market introduction (only significant in partial model 2). Finally, a late or no joining of a staff member in marketing/business increases the probability of delay in market introduction, but not at a significant level. Specific barri- 
ers or needs that emerge from this pattern, refer to specialized (advanced) information and to wider advantages of quick collaboration with large firms.

(3) Results on entrepreneurial ecosystems, as measured at national level (NIS) and local level (ranging from core metropolitan areas to smaller cities at large distances), show the following trends: a favorable NIS increases the probability of short time to market introduction, however, not at a significant level. In contrast, being established in a metropolitan area (largest city) tends to cause a longer time to market introduction (only significant in the full model). This trend may comply with stronger presence of more radical (more fundamental) inventions in metropolitan areas that require time-consuming and risk-taking research efforts to bridge the gap with more practical invention and market demand. Agglomeration (proximity) and network advantages in large cities are most probably not sufficiently strong to help accelerate taking steps to market introduction. Specific barriers or needs that emerge from this pattern, refer to better national programs, stimulating more applied research and entrepreneurship at university, and integrated start-up policies with a focus on 'technology readiness'.

Table 2. Cox Regression Results on Time to Market.

\begin{tabular}{|c|c|c|c|c|}
\hline Variables & $\begin{array}{c}\text { Model } 1 \\
\text { HR (s. e.) }\end{array}$ & $\begin{array}{c}\text { Model } 2 \\
\text { HR (s. e.) }\end{array}$ & $\begin{array}{l}\text { Model } 3 \\
\text { HR (s. e.) }\end{array}$ & $\begin{array}{c}\text { Model } 4 \\
\text { HR (s. e.) }\end{array}$ \\
\hline \multicolumn{5}{|l|}{ Strategic Choice (risks) } \\
\hline Invention radicalness & $0.30(0.09)^{* * *}$ & & & $0.21(0.08)^{* * *}$ \\
\hline Newness of market & $0.65(0.13)^{* *}$ & & & $0.56(0.12) * * *$ \\
\hline Business sector & $0.21(0.06)^{* * *}$ & & & $0.22(0.07)^{* * *}$ \\
\hline Diversification & $1.11(0.32)$ & & & $1.47(0.44)$ \\
\hline \multicolumn{5}{|l|}{ Competences/resources } \\
\hline Founding team size & & $1.07(0.12)$ & & $1.04(0.13)$ \\
\hline PhD as highest education & & $1.68(0.50)^{*}$ & & $2.72(0.98) * * *$ \\
\hline Business experience & & $1.00(0.36)$ & & $0.72(0.26)$ \\
\hline Joining of staff in marketing & & $0.87(0.12)$ & & $0.84(0.12)$ \\
\hline Time to first collaboration & & $0.76(0.10)^{* *}$ & & $0.92(0.16)$ \\
\hline Time to first investment & & $1.04(0.13)$ & & $0.85(0.13)$ \\
\hline \multicolumn{5}{|l|}{ Entrepreneurial ecosystem } \\
\hline Nat. innovation system & & & $1.49(0.37)$ & $1.27(0.39)$ \\
\hline Urban location & & & $0.93(0.09$ & $0.77(0.08)^{* *}$ \\
\hline No. of subjects & 106 & 106 & 106 & 106 \\
\hline LR Chi-square & 47.76 & 10.92 & 2.89 & 65.88 \\
\hline Log likelihood & -161.26 & -179.68 & -183.70 & -152.20 \\
\hline$p$ value & $<0.0001$ & 0.09 & 0.23 & $<0.0001$ \\
\hline
\end{tabular}

Significance levels: ${ }^{*} p<0.1 ;{ }^{* *} p<0.05 ;{ }^{* * *} p<0.01 ;$ HR: hazard ratio.

With regard to strength of the model, including the three partial models, we observe the following. The strongest single part of the model is strategic choice (model 1) (loglikelihood of -161.3). No other partial model has a better log-likelihood and higher level of significance. In the full model (model 4), competences and entrepreneurial ecosystem, nevertheless, contribute to a better log-likelihood (-152.2). Unfortunately, a broader interpretation of these results is hindered by (almost) lack of comparable empirical studies. Existing studies are either studies of different types of firms, like SMEs or focus on eco-innovation within firms' operations, or present a review of the literature $[66,82,83]$, eventually in combination with case study analysis of a small set of firms [84].

We checked robustness of the model (partial models and full model), with market introduction (yes/no) as dependent variable, and due to binary character of this variable, with logistic regression (Appendix E). The results point to similar outcomes compared with Cox model. Firstly, the strongest partial model is that of strategic choice, while 
competences and entrepreneurial ecosystem are relatively weak, and secondly, the last two partial models contribute to an overall stronger result (full model).

\subsection{Municipalities' Initiatives}

Using a mix of desk-research (firms' studies, press releases, websites etc., as well as literature about municipalities' involvement in experimentation (e.g., [6-8,11-15]) and interviews (note 1), we explore four firm barriers to a quick market introduction and indicate for each barrier what municipalities may provide in terms of supporting initiatives. The four initiatives $(\mathrm{a}-\mathrm{d})$ include risk-taking and investment, risk-taking and early experimentation, late start of collaboration with a large partner, and location in a large metropolitan area. Mentioning municipality initiatives in the text below, does not mean that all municipalities in the study have been engaged in the supportive initiatives, but some of them have shown in recent past or show today that particular initiatives can function well:

(a) Risk-taking and financial investment. Strategic choice that involves radical inventions and new markets, may cause high financial expenses of extended R\&D. If market introduction is delayed, while high amounts of venture capital have been granted, a scenario arises of pressure from too tight refunding schedules. Risk-taking through a radically improved product is exemplified by a spin-off involved in advanced membranes for upgrading of biogas (Norway, Trondheim, founded in 2008) [85]. Despite considerable investment by consortia, the spin-off had maintained an overall academic orientation while it operated various testing sites in Norway. Delay as a result of regulation issues, turned out to be critical, as the firm introduced the membranes to market under time pressure of a refunding scheme. As a result, quality issues emerged with the novel product in sales later-on. This development contributed to worsening of the firm's financial position, in such a way that the firm was forced to file for bankruptcy (2015).

Municipalities are seldom directly involved in providing venture capital (or similar investment). The current situation in The Netherlands is worth mentioning in this context, because of (potential) influence of municipalities. Some provinces have their own regional development corporations (RDCs) which act as venture capital companies that finance local business [86]. However, the investment sums are much smaller compared with private venture capital consortia as indicated above. Further roles of municipalities include being active in organizing meetings as 'qualified matchmaking' with financial investors in transitional change, eventually inviting business angels and organizers of crowdfunding.

(b) Risk-taking and early experimentation, incl. developing specialized information. Early access to 'sheltered' experimentation places (niches), in order to learn and 'fine-tune' with market demand (effectiveness), regulations (standards), scaling-up and business models, is increasingly seen as important [50-53]. Benefits of early experimentation can be illustrated with a spin-off engaged in smart charging systems for electrical vehicles (hardware and software) allowing for a significantly shorter charging time (The Netherlands, Delft, founded in 2005). The invention was successfully introduced to market after several local experimentation projects in a consortium (local municipality, potential customers, investors, electricity provider) culminating in the first real-life charging facility in Europe, co-organized by the municipality of Leeuwarden, in 2010 [87,88]. After accessing several global markets, the spin-off firm gave up attempts to further roll-out in these markets, and preferred to be acquired by a multinational firm that could undertake upscaling and global sales in a more powerful way. An example of a spin-off that benefits more recently from important local experimentation (e.g., regulation; customer preferences), is involved in solar energy equipment. It develops and manufactures flexible (curved) solar cells and integrates them, including the electronics, on street attributes, like lighting poles and traffic warning signals. The spin-off also develops solar cell solutions on roofs, modelled as roof tiles [89]. Founded in The Netherlands (Delft, in 2012), it is today market leader in curved solar cell solutions in Europe.

What municipalities may do-within the confines of their activities-is facilitation of (early) experimentation through assigning specific urban sites, and co-organization 
of part of the experimentation. Places of experimentation are in certain living quarters, public parks, streets, at university campus, hospitals, sporting fields/accommodation, and public transport stations. Municipalities are particularly involved if the infrastructure or accommodation is owned and managed by themselves. A recent example is the municipality of Lund (Sweden), that provides particular road sections to fix a road system for dynamic charging of electric vehicles (while driving), with the aim of experimentation and demonstration, thereby developing advanced information. The project is co-organized with a spin-off firm, the university, and several actors in transportation [90].

(c) Time of start of collaboration, incl. developing specialized information. Early partnering is important as it provides core or additional resources to spin-off firms, for example, as 'compensation' for specialized information that is absent in the founding team. However, to find a trustworthy partner-as perceived by a vulnerable small firm-is not that easy. It requires credibility of the small firm itself and fair agreements with the partner, e.g., in dealing with intellectual ownership. Strong importance of connecting with the right partners and focusing on key collaboration, can be illustrated with a spin-off developing a gearless wind turbine system (Norway, Trondheim, founded in 2006). Despite large amounts of investment capital [91,92], the firm was not able to solidly connect and collaborate with large Danish or German traditional wind turbine producers, to make the difference with its radical invention. It also faced substantial problems with a supplier of a key new pump, causing delay, and consequently, it made not sufficient progress in reaching the market. As a result, refunding of substantial loans had to be postponed, ultimately causing the need to file for bankruptcy (2013). We next mention a positive example of realized partnering (The Netherlands, Amsterdam, founded in 2008). With the aim to produce biofuel, the spin-off developed a platform technology of specially grown bacteria that thrive on $\mathrm{CO}_{2}$ and sunlight. While production of biofuel turned out to be not yet feasible, the firm started to diversify in producing related chemical compounds, in collaboration with specialized partners [93]. This strategy enabled to self-finance further research on upscaling of biofuel production. However, the attention for a broader range of products may also cause a delay in development and market introduction of biofuel.

What municipalities may do when local spin-offs face difficulty in finding a large commercial partner, is to act as a collaborating partner (launching customer) by themselves and provide direct support in market introduction. The range of inventions and the financial involvement are of course limited due to regulations, but they may include urban green, street attributes (lightning), urban public transport, local traffic regulation systems, car parking management, energy efficiency in municipality buildings, and municipality parks producing solar energy and wind energy. The related 'start-up-in-residence' is a rather new initiative (started in San Francisco) [94] and provides spin-off firms with opportunities to match their product/service with municipal needs, in a more tight relationship in situ, thereby also improving image and credibility towards established firms and investors.

(d) Location in large metropolitan areas. Our results indicate a high probability of delay in market introduction in large metropolitan areas. We may partially understand this situation as stronger presence of more creative or fundamental research and radically new inventions by spin-offs here. A better application of advantages of national energy research and incentive programs (NIS) is important, as these pave the way for more applied development activity at university and establishing and funding of spin-off firms that have passed the stage of fundamental research. For example, the national policy in Sweden to favor solar energy (thermal and electrical) since 2016, caused a boost in research on storage, e.g., batteries for residential use [95]. Most important, however, are the professional (experienced) start-up networks and communities developed since the early 2000s, from which young technology firms in early stages benefit using e.g., business idea testing, incubator and accelerator programs, personal coaching, access to lab space and maker space, and access to investors. STING is an example in Stockholm [96]. It is owned by a public-private foundation that consists of business actors, academia, and the public sector (City of Stockholm, Stockholm County Council, etc.). Such structure would allow a 
certain steering by municipalities (as network partner) on the kind of support provided and type of technology solution applied in the city, as well as advice on 'technology readiness' of the start-ups. Municipalities in metropolitan areas may also support local universities in focusing on national energy transition issues in research and education (curriculum development), and in practice-oriented entrepreneurship, thereby stimulating local scientists and students to unleash their commercialization potentials. In addition, municipalities may lobby internationally for election in EU support programs, including R\&D subsidies, practical experimentation projects, etc.

We may summarize that policies by municipalities like the ones above, are most often realized in collaboration or as partner in a consortium, and mainly work indirectly (Table 3). The policies are solid and also rather varied, however, they lack an integrated approach and pro-activeness over the past years, and have received priority only recently. We may suggest that, if integration - the last regarding energy start-ups but also regarding links with other energy policies-and pro-activeness are part of a planning strategy with high priority, the municipal level is a promising level to address transitional change through young technology firms.

Table 3. Municipalities' Initiatives and Ways of Working in Supporting Young Technology Firms.

\begin{tabular}{|c|c|c|}
\hline Category & Young Technology Firms' Needs & Ways of Working (Partial Overlap) \\
\hline Financial & Substantial investment (soft refunding) & $\begin{array}{l}\text { Partnering (or merely lobbying) in investment } \\
\text { consortium or smaller partnership }\end{array}$ \\
\hline $\begin{array}{l}\text { (Traditional) Accommodation and } \\
\text { training programs }\end{array}$ & $\begin{array}{l}\text { Cheap accommodation and training (e.g., } \\
\text { on survival, risk-reduction, acceleration) }\end{array}$ & Co-investor, with university and large firms \\
\hline $\begin{array}{l}\text { Experimentation and learning } \\
\text { (niches) }\end{array}$ & $\begin{array}{l}\text { Specialized information on practice: pilot } \\
\text { testing, field lab, living lab, etc. (about } \\
\text { effectiveness, upscaling, regulation, } \\
\text { customer needs, business models) }\end{array}$ & $\begin{array}{l}\text { Co-organizer, with university, large } \\
\text { firms, citizens }\end{array}$ \\
\hline Market (as learning context) & $\begin{array}{l}\text { Specialized information about customer } \\
\text { needs, pricing, business models }\end{array}$ & Launching customer \\
\hline Networking & Match with large firms and investors & $\begin{array}{l}\text { Qualified matchmaker, eventually in large } \\
\text { stakeholder setting }\end{array}$ \\
\hline $\begin{array}{l}\text { Professional start-up networks and } \\
\text { communities }\end{array}$ & $\begin{array}{l}\text { Supportive networks and community for } \\
\text { accessing advanced information, } \\
\text { competences, etc. }\end{array}$ & $\begin{array}{l}\text { Steering and co-financing of tech start-up } \\
\text { networks and communities; acting as } \\
\text { intermediary and lobbyist; enhancing } \\
\text { university role (new technology, talents), as } \\
\text { partner in a public private partnership }\end{array}$ \\
\hline $\begin{array}{l}\text { Comprehensive ecosystem } \\
\text { in cluster }\end{array}$ & $\begin{array}{l}\text { Above mentioned; eventually also better } \\
\text { connection with large firms and R\&D in } \\
\text { and outside cluster }\end{array}$ & $\begin{array}{l}\text { Above mentioned, incl. negotiation, } \\
\text { coordination, lobbying, etc. at different } \\
\text { functional system levels; also at different } \\
\text { territorial and governance levels }\end{array}$ \\
\hline
\end{tabular}

\subsection{Driving Energy Transition by Cluster Development}

The much more comprehensive driving of transition by building sustainable energy clusters, will be briefly discussed in this section. We make use of emerging energy cluster literature [97-101], by summarizing critical success factors. We recognize that at start of cluster building, important existing (traditional) specialization advantages in the region can be utilized. This is, for example, evident in planning of 'green hydrogen valleys' in EU, e.g., in North-Netherlands, using benefits from presence of pipelines, process industry, a seaport, off-shore wind farms, etc. connected to natural gas production [101]. Similarly, offshore wind cluster development, e.g., in Southern Denmark, at the time benefited from off-shore oil/gas exploitation and a well-equipped seaport (Esbjerg) [98]. However, critical success factors in building energy clusters include a lot more: Triple Helix configuration enabling upscaling of inventions; national (EU) level steering and 
investments; well-developed housing markets and living conditions to attract and retain top-level researchers; integration of citizen participation into cluster programs; and strong negotiation, coordination and governance capabilities of the leading municipality. These factors will be briefly addressed below.

A critical requirement in transitional cluster building is attracting and nurturing main parts of R\&D chains in the region, including places of experimentation and firms (large and small) that produce and firms that use the novel technology. Further, Triple Helix configuration and collaboration [67,102-105] should enable and promote upscaling of the transitional technology to reach wider application than the city and region involved. Accordingly, integration of network dynamics of intellectual capital of universities, wealth creation of industries, the democratic government of civil society and increasing customer involvement [104], enables reaping the fruits of a solid Triple Helix system that is anchored in the region with major bridges to other regions and countries. Such comprehensive activity and transitional mission require national level steering and financial investment, as the budgets needed by far exceed local budget levels. Furthermore, there are two local situations that are required to be well developed. Firstly, high-quality housing and living conditions to better attract and retain top-class researchers and developers, such as in the British Columbia/Vancouver (Canada) hydrogen cluster [97], and secondly, integration of citizen participation into the cluster program, eventually using experimentation spaces. Citizen participation affects problem definition and recognition, and co-creation of solutions specifically in urban energy issues, mainly housing and transport. A still to resolve issue is the democratic character of citizen participation, as often citizens are involved derived from self-selection, potentially causing bias in results [74,76]. But the creation of an atmosphere of respect for bottom-up (civic) initiatives and overall community acceptance of transitional change [106], helps to unleash entrepreneurial potentials in an overall better development of new energy solutions 'from the ground'.

Cluster development is a long-term management and governance effort in which the main municipalities collaborate with a regional authority or consortium (of which governance power should be clearly defined) [98]. As previously indicated, there are also important networks at higher spatial scales involved, namely, national and European R\&D and investment programs, aside from connections with different functional systems which have their own dynamics. This situation of multiple networking requires strongly developed negotiation, coordination and governance capabilities. As a consequence, building of technology-driven clusters is faced with much uncertainty [107]. Uncertainty originates not only in dynamic interaction between stakeholders (governors), but also in dealing with the focal technology, due to competition and danger of being overruled by more advanced or cheaper technology, and in dealing with dynamics in macro-economic situations, as an external factor.

The design of solutions for management of uncertainty requires understanding the origins and background to uncertainty $[107,108]$ and of adaptive approaches to planning and governance. In adaptive governance, instead of standard models, stability and accountability, learning is the core value. Adaptive governance therefore, is also about ability of planning organizations themselves (including leading municipalities) to increase their adaptive capacity in an overall wish to improve own learning, but also speed of decisionmaking [109]. Adaptive approaches encompass the design of flexible, broad planning goals and concrete projects at short cycle times, with signposts on the way. Adaptive approaches in planning, however, are not easy to implement, as there is a lack of experience and evidence-based methods that work [110], but progress is made, thanks to simulation modelling, serious gaming, etc. [111,112]. Such circumstances, once more, put heavy load on the shoulders of leading municipalities.

\section{Conclusions}

The aim of this article was to develop understanding of market introduction of energy inventions by young technology firms and of initiatives of municipalities to support these 
firms, which is new in the context of energy transitions. Drawing on a sample of university spin-offs in the Nordic countries and The Netherlands, it appeared that $40 \%$ of all firms failed in market introduction in the past years, and that reaching the market was rather late for $30 \%$, underlining urgency of attention in research and policy making. With regard to factors influencing the time needed in market introduction, risk-taking strategies-radically new products/services and new or emerging markets-appeared to be most important. Municipalities have taken initiatives to support such firms for many years, but often in a fragmented way, without much priority, like financial investment (indirectly); accommodation and training programs; real-life experimentation places and projects; acting as launching customer and as 'connecting' actor. An important improvement is municipalities' involvement in professional technology start-up networks and communities, like STING, Stockholm [96]. If better integrated and higher priority, the initiatives all-in-all indicate a good future for transition planning and policy at the level of municipalities. Municipalities may, however, also drive energy transition using a comprehensive regional cluster policy. In such initiative, municipalities are faced with important challenges, like extended Triple Helix activity, well-developed housing market and living conditions, and integration of citizen participation in developing solutions, in particular acceptance of transition by citizens. The need for municipalities to deal with concomitant dependencies on other territory, different functional systems and governance levels-and related complexity and uncertainty, make us tentatively argue that not all (large) municipalities qualify to drive energy transition, unless within a consortium that owns strong capabilities in management and policy-making. This vision is, however, based on fragments in literature, reflecting the current gap between the required driving of transitions and scope of existing empirical work.

The study has some limitations. Firstly, a narrow scope in investigation of market introduction through the channel of young technology firms. There is a range of channels of market introduction, such as licensing of university patents to large firms and universityindustry contract research [113]. Secondly, several relevant research areas have remained beyond the scope of the study, i.e., on the side of municipalities and of young technology firms (and mutual relationships). On the side of municipalities, there are questions concerning the influence of the urban/regional economic sector structure [114], like dominance of high-technology research and manufacturing, and whether this stimulates spin-offs to be involved in more radical inventions and new markets that would take a longer time to market introduction, calling for specific policy attention [25]. On the side of young technology firms, questions arise about our assumption that targeting early market introduction would be the best strategy. Our results indicate that the situation is more nuanced, e.g., dependent on financial pressure and maturity of the new technology, requiring additional research. We also recommend further research on ways in which professional start-up organizations and community networks can be extended to more cities in EU and beyond, particularly on legal formats (foundation, public-private partnership, not-for-profit) which enable meaningful influence of municipalities on start-up support. Furthermore, many municipalities collaborate in (learning) networks, like the C40 Cities Climate Leadership Group (largest world cities) [115] and the more recent EnergyCities in Europe [116]. Increasingly, such networks aim at capacity building among local governors and citizens, like on contractual and governance models serving joint initiatives (communities) [116,117]. Our article's focus on young technology entrepreneurship, hopefully, will attract more attention in municipal planning and in mutual learning to technology creation, market introduction and upscaling, which also deserves further research. Clearly, we deal with a differentiated field, but also with needs for balanced decisions, and accordingly, we are facing a wealth of future research on municipalities' planning of transitional change.

Note 1. Semi-open interviews were held by the first author with Professor dr. James Evans in Manchester (UK), 13-04-2017 concerning urban living labs and the university; and with Jaron Weishut (MSc) in Delft (NL), 27-11-2018 concerning field labs, university and municipality. 
Author Contributions: Problem definition, research design: M.V.G.; data collection (shared): M.V.G. R.N.; modelling and validation: R.N.; management and checks: M.V.G. All authors have read and agreed to the published version of the manuscript.

Funding: Not applicable.

Institutional Review Board Statement: Not applicable.

Informed Consent Statement: Not applicable.

Conflicts of Interest: The authors declare no conflict of interest.

Appendix A. Cities in the Study

\begin{tabular}{cc}
\hline Norway & Oslo (core metropolitan) a), Trondheim, Stavanger, Tromsø \\
\hline Sweden & $\begin{array}{r}\text { Stockholm (core metropolitan), Uppsala, Umea, Lund-Malmø, } \\
\text { Gothenburg, Linkoping, Sundsvall }\end{array}$ \\
\hline Finland & Helsinki (core metropolitan), Tampere, Lappeenranta, Joensuu, \\
Kuopio, Mikkeli
\end{tabular}

\section{Appendix B. Model Variables, Measurement and Descriptive Results}

\begin{tabular}{|c|c|c|}
\hline Variables & $\begin{array}{l}\text { Measurement and } \\
\text { Measurement (Scale) }\end{array}$ & Results \\
\hline \multicolumn{3}{|l|}{ Dependent } \\
\hline $\begin{array}{l}\text { Time to market } \\
\text { introduction (MI) }\end{array}$ & $\begin{array}{l}\text { Number of years between } \\
\text { firm establishment and first } \\
\text { sale }{ }^{*} \text { (continuous) }\end{array}$ & $\begin{array}{c}\text { Reached MI: Average }=4.42 ; \mathrm{SD}=3.24 ; \\
\text { Min-max: } 1-14 \\
\text { MI not reached: Average = 7.22; } \\
\text { SD = 2.8; } \\
\text { Min-max: } 2-13\end{array}$ \\
\hline \multicolumn{3}{|l|}{ Independent } \\
\hline Invention radicalness & $\begin{array}{l}\text { Newness of innovation to } \\
\text { the market and industry } \\
\text { (ordinal) }\end{array}$ & $\begin{array}{c}1=\text { More incremental }(59.4 \%) ; 2=\text { More } \\
\text { radical }(40.6 \%)\end{array}$ \\
\hline Newness of market & $\begin{array}{l}\text { Newness of the market } \\
\text { (ordinal) }\end{array}$ & $\begin{array}{c}1=\text { Established market }(25.5 \%) ; \\
2=\text { Emerging market }(55.6 \%) ; 3=\mathrm{New} \\
\text { market }(18.9 \%)\end{array}$ \\
\hline Business sector & $\begin{array}{c}\text { Services or } \\
\text { manufacturing-oriented } \\
\text { (ordinal) }\end{array}$ & $\begin{array}{c}1=\text { Services }(25.5 \%) \\
2=\text { Manufacturing-oriented }(74.5 \%)\end{array}$ \\
\hline Diversification & $\begin{array}{c}\text { Diversified product or } \\
\text { diversified market (ordinal) }\end{array}$ & $\begin{array}{c}1=\text { Diversified }(51.9 \%) ; 2=\text { Focus } \\
(48.1 \%)\end{array}$ \\
\hline Founding team size & $\begin{array}{l}\text { Number of founding team } \\
\text { members (continuous) }\end{array}$ & $\begin{array}{c}\text { Average }=2.16 ; \mathrm{SD}=1.19 ; \text { Min-max: } \\
1-6\end{array}$ \\
\hline $\begin{array}{l}\text { PhD as highest } \\
\text { education }\end{array}$ & $\begin{array}{l}\text { Level of highest educational } \\
\text { degree among founding } \\
\text { team (ordinal) }\end{array}$ & $\begin{array}{c}1=\operatorname{PhD}(72.0 \%) ; 2=\text { Master or below } \\
(28 \%)\end{array}$ \\
\hline
\end{tabular}




\begin{tabular}{|c|c|c|}
\hline Business experience & $\begin{array}{l}\text { Pre-start business } \\
\text { experience in founding of a } \\
\text { firm and/or firm } \\
\text { management (binary) }\end{array}$ & $1=$ Yes $(48.1 \%) ; 2$ = No $(51.9 \%)$ \\
\hline $\begin{array}{l}\text { Joining of staff in } \\
\text { marketing }\end{array}$ & $\begin{array}{l}\text { Joining of first } \\
\text { marketing/business staff } \\
\text { member (ordinal) }\end{array}$ & $\begin{array}{c}1=\text { Among founders }(47.2 \%) ; 2=\text { After } \\
\text { firm's foundation }(23.6 \%) ; 3=\text { Not till } \\
2018(29.2 \%)\end{array}$ \\
\hline $\begin{array}{l}\text { Time to first } \\
\text { collaboration }\end{array}$ & $\begin{array}{l}\text { Time to first main } \\
\text { collaboration (large firm(s)) }\end{array}$ & $\begin{array}{c}1=\text { First year }(22.6 \%) ; 2=\text { Between age } \\
2 \text { and } 4(36.8 \%) ; \\
3=\text { In age } 5 \text { or later }(18.9 \%) ; 4=\text { Never } \\
(21.7 \%)\end{array}$ \\
\hline $\begin{array}{l}\text { Time to first } \\
\text { investment }\end{array}$ & $\begin{array}{l}\text { Time to receiving the first } \\
\text { substantial financial } \\
\text { investment (ordinal) }\end{array}$ & $\begin{array}{c}1=\text { First year }(12.3 \%) ; 2=\text { Between age } \\
2 \text { and } 4(28.3 \%) ; \\
3=\text { In age } 5 \text { or later }(16 \%) ; 4=\text { Never } \\
(43.4 \%)\end{array}$ \\
\hline NIS & $\begin{array}{l}\text { National Innovation System } \\
\text { of countries (ordinal) }\end{array}$ & $\begin{array}{c}1=\text { Finland, Sweden, Denmark (52.8\%); } \\
2 \text { = Norway, Netherlands }(47.2 \%)\end{array}$ \\
\hline Urban location & $\begin{array}{l}\text { Cities according to size and } \\
\text { distance to core } \\
\text { metropolitan area (ordinal) }\end{array}$ & $\begin{array}{c}1=\text { Core metropolitan area }(41.5 \%) ; \\
2=\text { Adjacent (max. } 80 \mathrm{~km} \text { distance) } \\
(15.1 \%) ; 3=\text { Large (more than } \\
250,000 \text { residents) at far distance }(9.4 \%) ; \\
4=\text { Small cities at far distance }(34 \%)\end{array}$ \\
\hline
\end{tabular}

\section{Appendix C. Correlation Matrix}

\begin{tabular}{|c|c|c|c|c|c|c|c|c|c|c|c|c|}
\hline Model Variables & 1 & 2 & 3 & 4 & 5 & 6 & 7 & 8 & 9 & 10 & 11 & 12 \\
\hline $\begin{array}{l}\text { 1. Time to market } \\
\text { introduction }\end{array}$ & 1 & & & & & & & & & & & \\
\hline $\begin{array}{l}2 . \text { Invention } \\
\text { radicalness }\end{array}$ & $0.35^{*}$ & 1 & & & & & & & & & & \\
\hline 3. Diversification & 0.04 & 0.16 & 1 & & & & & & & & & \\
\hline $\begin{array}{l}\text { 4. Newness of } \\
\text { market }\end{array}$ & $0.29^{*}$ & $0.20 *$ & 0.05 & 1 & & & & & & & & \\
\hline 5. Business sector & $0.39 *$ & $0.30 *$ & $0.21^{*}$ & 0.14 & 1 & & & & & & & \\
\hline $\begin{array}{l}\text { 6. Founding team } \\
\text { size }\end{array}$ & -0.12 & -0.05 & -0.04 & -0.07 & -0.02 & 1 & & & & & & \\
\hline $\begin{array}{l}\text { 7. PhD as highest } \\
\text { education }\end{array}$ & -0.18 & 0.11 & -0.06 & -0.04 & -0.19 & $-0.23 *$ & 1 & & & & & \\
\hline $\begin{array}{l}\text { 8. Business } \\
\text { experience }\end{array}$ & -0.17 & -0.12 & 0.09 & 0.05 & -0.04 & $0.25^{*}$ & 0.10 & 1 & & & & \\
\hline $\begin{array}{l}\text { 9. Joining of staff in } \\
\text { marketing }\end{array}$ & 0.13 & 0.02 & -0.1 & -0.04 & 0.00 & $-0.23^{*}$ & -0.09 & $-0.74^{*}$ & 1 & & & \\
\hline $\begin{array}{l}\text { 10. Time to first } \\
\text { collaboration }\end{array}$ & $0.26 *$ & 0.09 & 0.02 & -0.03 & 0.12 & -0.05 & -0.08 & -0.15 & 0.11 & 1 & & \\
\hline $\begin{array}{l}\text { 11. Time to first } \\
\text { investment }\end{array}$ & -0.06 & -0.09 & 0.08 & -0.14 & $-0.34^{*}$ & -0.16 & 0.10 & -0.17 & $0.27^{*}$ & $0.20 *$ & 1 & \\
\hline 12. NIS & -0.14 & -0.08 & -0.11 & -0.14 & -0.14 & 0.05 & 0.11 & -0.18 & $0.20 *$ & -0.17 & $0.23 *$ & 1 \\
\hline 13. Urban location & 0.00 & 0.00 & 0.11 & $-0.22 *$ & -0.12 & 0.05 & -0.08 & 0.00 & -0.11 & 0.05 & 0.13 & -0.03 \\
\hline
\end{tabular}

\section{Appendix D}

\section{Appendix D.1. Cox Model Specification}

The Cox model can be specified as follows:

$$
h(t ; x)=h_{0}(t) e^{\beta x}
$$


where: $h_{0}(t)$ is the baseline hazard; the baseline hazard is the hazard when covariate $x$ is equal to zero, thus $e^{\beta x}=1 ; x$ is a covariate and $\beta$ is a parameter calculated to represent the effect of the covariate on the outcome. In fact $\beta$ shows that for each unit increase in the covariate $x$, the hazard will be multiplied by $e^{x}$. If more than one covariate is added to the Cox proportional model, the extended form of the equation is written as follows:

$$
h\left(t ; x_{1}, \ldots, x_{n}\right)=h_{0}(t) e^{\beta_{1} x_{1}+, \ldots+\beta_{n} x_{n}}
$$

Appendix D.2. Cox Proportional-Hazards Assumption Test

We test proportional-hazards assumption based on Schoenfeld residuals (STATA). The table below shows that neither in the detailed test (per variable) nor in the overall test, the $\mathrm{p}$-value is close to zero. Therefore, the proportional hazard assumption is not violated by our data.

Table A1. Results of proportional-hazards assumption test.

\begin{tabular}{ccccc}
\hline Variables & Rho & $\mathbf{C h i}^{\mathbf{2}}$ & Df & $p$-Value \\
\hline Radicalness (invention) & 0.051 & 0.20 & 1 & 0.65 \\
\hline Newness of market & 0.08 & 0.46 & 1 & 0.49 \\
\hline Business sector & 0.145 & 1.60 & 1 & 0.20 \\
\hline Diversification & -0.154 & 1.77 & 1 & 0.18 \\
\hline Founding team size & 0.031 & 0.11 & 1 & 0.74 \\
\hline PhD as highest education & -0.050 & 0.20 & 1 & 0.65 \\
\hline Business experience & -0.105 & 0.62 & 1 & 0.29 \\
\hline Joining of marketing staff & -0.14 & 1.56 & 1 & 0.21 \\
\hline Time to first collaboration & -0.07 & 0.68 & 1 & 0.41 \\
\hline Time to first investment & -0.046 & 0.14 & 1 & 0.70 \\
\hline NIS & 0.09 & 0.62 & 1 & 0.43 \\
\hline Urban location & -0.06 & 0.34 & 1 & 0.56 \\
\hline Overall test & 8.93 & 14 & 1 & 0.84 \\
\hline
\end{tabular}

\section{Appendix E. Robustness of Model}

We tested explanatory power and significance of the model composition. However, with a different but related independent variable, namely market introduction yes/no, and using another type of regression (logistic). The table below shows statistical results for the partial models and full model. These point to similar outcomes compared with estimation of Cox model: the strongest partial model is that of strategic choice (risk-taking), while competences / resources and entrepreneurial ecosystem are relatively weak. Similarly, the last two partial models contribute to an overall stronger result (Full model). In detail, however, there are some differences with regard to significance of competence factors.

Table A2. Statistical results of the regression model.

\begin{tabular}{ccccc}
\hline Results & $\begin{array}{c}\text { Strategic Choice } \\
\text { (Risks) }\end{array}$ & $\begin{array}{c}\text { Competences/ } \\
\text { Resources }\end{array}$ & $\begin{array}{c}\text { Entrepreneurial } \\
\text { Ecosystem }\end{array}$ & Full Model \\
\hline Pseudo R & 0.23 & 0.11 & 0.03 & 0.34 \\
\hline Log-likelihood & -54.31 & -68.18 & -69.87 & -46.91 \\
\hline Model significance & $<0.0001$ & 0.53 & 0.42 & $<0.0001$ \\
\hline
\end{tabular}




\section{References}

1. United Nations. Climate Change Paris Agreement. 2016. Available online: https://unfccc.int/files/essential_background/ convention/application/pdf/english_paris_agreement.pdf (accessed on 22 July 2020).

2. World Economic Forum. The Great Reset: How Cities are Leading the Energy Transition. 2020. Available online: https: //www.weforum.org/agenda/2020/08/role-of-cities-in-energy-transition/ (accessed on 30 September 2020).

3. Eurocities. 2020. Available online: www.eurocities.eu/goals/climate-change-and-energy-transition/2020 (accessed on 20 September 2020).

4. Bulkeley, H.; Betsill, M. Rethinking sustainable cities: Multilevel governance and the 'urban' politics of climate change. Environ. Politics 2005, 14, 42-63. [CrossRef]

5. Bulkeley, H.; Broto, V.C. Government by experiment? Global cities and the governing of climate change. Trans. Inst. Br. Geogr. 2012, 38, 361-375. [CrossRef]

6. Evans, J.; Karvonen, A.; Raven, R. The Experimental City; Routledge: Milton Park, UK, 2017.

7. Fuenfschilling, L.; Frantzeskaki, N.; Coenen, L. Urban experimentation and sustainability transitions. Eur. Plan. Stud. 2019, 27. [CrossRef]

8. Van Doren, D.; Giezen, M.; Driessen, P.; Runhaar, H. Scaling-up energy conservation initiatives: Barriers and local strategies. Sustain. Cities Soc. 2016, 26, 227-239. [CrossRef]

9. Van Geenhuizen, M.; Berti Suman, A. From citizen sensing to citizen living lab: In search of key performance factors in coproduction of healthcare solutions. In Proceedings of the 59th ERSA Congress Regional Science Association, Lyon, France, 27-30 August 2019.

10. Nyström, A.-G.; Leminen, S.; Westerlund, M.; Kortelainen, M. Actor roles and role patterns influencing innovation in living labs. Ind. Mark. Manag. 2014, 43, 483-495. [CrossRef]

11. Voytenko, Y.; McCormick, K.; Evans, J.; Schwila, G. Urban living labs for sustainability and low carbon cities in Europe: Towards a research agenda. J. Clean. Prod. 2016, 123. [CrossRef]

12. Marvin, S.; Bulkeley, H.; Mai, L.; McCormick, K.; Palgan, Y.V. Urban Living Labs. Experimenting with City Futures; Routledge: Milton Park, UK, 2018.

13. Nesti, G. Co-production for innovation: The urban living lab experience. Policy Soc. 2017, 37, 310-325. [CrossRef]

14. Von Wirth, T.; Fuenfschilling, L.; Frantzeskaki, N.; Coenen, L. Impacts of urban living labs on sustainability transitions: Mechanisms and strategies for systemic change through experimentation. Eur. Plan. Stud. 2019, 27, 229-257. [CrossRef]

15. Hossain, M.; Leminen, S.; Westerlund, M. A systematic review of living lab literature. J. Clean. Prod. 2019, 213, 976-988. [CrossRef]

16. Brown, J.; Hendry, C.; Harborne, P. Developing radical technology for sustainable energy markets. Int. Small Bus. J. Res. Entrep. 2007, 25, 603-629. [CrossRef]

17. Burch, S.; Schroeder, H.; Rayner, S.; Wilson, J. Novel multi-sector networks and entrepreneurship in Metro Vancouver: A study of small business as an emerging non-state actor on climate change mitigation. Environ. Plan. C 2013, 31, 822-840. [CrossRef]

18. Westman, L.; Luederitz, C.; Kundurpi, A.; Mercado, A.; Weber, O.; Burch, S. Sustainability transitions through bottom-up dynamics: Re-conceptualizing SMEs from the perspective of social practices. Bus. Strategy Environ. 2019, 28, 388-402. [CrossRef]

19. Nejabat, R.; Van Geenhuizen, M. Entrepreneurial risk-taking in sustainable energy: University spin-off firms and market introduction in Northwest Europe. Sustainability 2019, 11, 6952. [CrossRef]

20. Anselin, L.; Varga, A.; Acs, Z. Local geographic spillovers between university research and high technology innovations. J. Urban Econ. 1997, 42, 422-448. [CrossRef]

21. McCann, P. Urban and Regional Economics; Oxford University Press: Oxford, UK, 2006.

22. Florida, R.; Adler, P.; Mellander, C. The city as innovation machine. Reg. Stud. 2017, 51, 86-96. [CrossRef]

23. Acs, Z.J.; Stam, E.; Audretsch, D.B.; O'Connor, A. The lineages of the entrepreneurial ecosystem approach. Small Bus. Econ. 2017, 49, 1-10. [CrossRef]

24. Van Geenhuizen, M.; Holbrook, J.A. Roles of cities and governance in sustainability transitions: Challenges in leadership. In Cities and Sustainable Technology Transitions; Edward Elgar Publishing: Cheltenham, UK, 2018; pp. 384-392.

25. Van Geenhuizen, M.; Nejabat, R.; Stek, P. Large cities as the cradle of sustainable energy innovation. In New Frontiers in Regional Science: Asian Perspectives; Springer International Publishing: Berlin/Heidelberg, Germany, 2021; pp. 329-345.

26. Lundvall, B. National innovation systems-Analytical concept and development tool. Ind. Innov. 2007, 14, 95-119. [CrossRef]

27. Jacobsson, S.; Bergek, A. Innovation system analysis and sustainability by transition: Contributions and suggestion for research. Environ. Innov. Soc. Transit. 2011, 1, 41-57. [CrossRef]

28. Fagerberg, J.; Fosaas, M. Innovation and Innovation Policy in Nordic Regions; University of Oslo: Oslo, Norway, 2014.

29. Kamp, L.; Smits, R.; Andriesse, C. Notions on learning applied to wind turbine development in NL and Denmark. Energy Policy 2004, 32, 1625-1637. [CrossRef]

30. Lilliestam, J.; Thonig, R.; Späth, L.; Caldés, N.; Lechón, Y.; Del Río, P.; Escribano, G.; Touza, L.L. Policy Pathways for the Energy Transition in Europe and Selected European Countries; Deliverable 7.2 MUSTEC Project, Deliverable 1 SCCER JA IDEA; ETH: Zürich, Switzerland, 2019.

31. Pirnay, F.; Surlemont, B.; Nlemvo, F. Toward a typology of university spin-off firms. Small Bus. Econ. 2003, 21, 355-369. [CrossRef]

32. Shane, S. Academic Entrepreneurship: University Spin-Offs and Wealth Creation; Edward Elgar: Cheltenham, UK, 2004. 
33. Vohora, A.; Wright, M.; Lockett, A. Critical junctures in the development of university high-tech spin-out companies. Res. Policy 2004, 33, 147-175. [CrossRef]

34. Van Geenhuizen, M.; Soetanto, D.P. Academic spin-offs at different ages: A case study in search of key obstacles to growth. Technovation 2009, 29, 671-681. [CrossRef]

35. Hockerts, K.; Wüstenhagen, R. Greening Goliaths versus emerging Davids-Theorizing about the role of incumbents and new entrants in sustainable entrepreneurship. J. Bus. Ventur. 2010, 25, 481-492. [CrossRef]

36. Hoogendoorn, B.; Van Der Zwan, P.; Thurik, R. Sustainable entrepreneurship: The role of perceived barriers and risk. J. Bus. Ethic 2019, 157, 1133-1154. [CrossRef]

37. Lavie, D. The competitive advantage of interconnected firms: An extension of the resource-based view. Acad. Manag. Rev. 2006, 31, 638-658. [CrossRef]

38. Van Geenhuizen, M.; Ye, Q. Responsible innovators: Open networks on the way to sustainability transitions. Technol. Forecast. Soc. Chang. 2014, 87, 28-40. [CrossRef]

39. Amelang, S. Energy Transition Start-Ups Shake-up the Business World. Clean Energy Wire. 11 July 2019. Available online: https: / / www.cleanenergywire.org (accessed on 20 September 2020).

40. Dóci, G.; Vasileiadou, E.; Petersen, A.C. Exploring the transition potential of renewable energy communities. Futures 2015, 66, 85-95. [CrossRef]

41. Ruggiero, S.; Martiskainen, M.; Onkila, T. Understanding the scaling-up of community energy niches through strategic niche management theory: Insights from Finland. J. Clean. Prod. 2018, 170, 581-590. [CrossRef]

42. Dijk, M.; De Kraker, J.; Hommels, A. Anticipating constraints on upscaling from urban innovation experiments. Sustainability 2018, 10, 2796. [CrossRef]

43. Naber, R.; Raven, R.; Kouw, M.; Dassen, T. Scaling up sustainable energy innovations. Energy Policy 2017, 110, 342-354. [CrossRef]

44. Geels, F.W. Ontologies, socio-technical transitions (to sustainability), and the multi-level perspective. Res. Policy 2010, 39, 495-510. [CrossRef]

45. Smith, A.; Voß, J.-P.; Grin, J. Innovation studies and sustainability transitions: The allure of the multi-level perspective and its challenges. Res. Policy 2010, 39, 435-448. [CrossRef]

46. Geels, F.W. Regime resistance against low-carbon transitions: Introducing politics and power into the multi-level perspective. Theory Cult. Soc. 2014, 31, 21-40. [CrossRef]

47. Markard, J.; Wirth, S.; Truffer, B. Institutional dynamics and technology legitimacy. A framework and a case study on biogas technology. Res. Policy 2016, 330-344. [CrossRef]

48. Geels, F.W. From sectoral systems of innovation to socio-technical systems: Insights about dynamics and change from sociology and institutional theory. Res. Policy 2004, 33, 897-920. [CrossRef]

49. Geels, F.W. Processes and patterns in transitions and system innovations: Refining the coevolutionary multi-level perspective. Technol. Forecast. Soc. Chang. 2005, 72, 681-696. [CrossRef]

50. Lopolito, A.; Morone, P.; Sisto, R. Innovation niches and socio-technical transitions: A case study of bio-refinery production. Futures 2011, 43, 27-38. [CrossRef]

51. Smith, A.; Raven, R. What is protective space? Reconsidering niches in transition to sustainability. Res. Policy 2012, 41, 1025-1036. [CrossRef]

52. Quitzau, M.-B.; Hoffmann, B.; Elle, M. Local niche planning and its strategic implications for implementation of energy-efficient technology. Technol. Forecast. Soc. Chang. 2012, 79, 1049-1058. [CrossRef]

53. Raven, R.; Kern, F.; Verhees, B.; Smith, A. Niche construction and empowerment through socio-political work. A meta-analysis of six low-carbon technology cases. Environ. Innov. Soc. Trans. 2016, 18, 164-180. [CrossRef]

54. Covin, J.G.; Lumpkin, G.T. Entrepreneurial orientation theory and research: Reflections on a needed construct. Entrep. Theory Pract. 2011, 35, 855-872. [CrossRef]

55. Shan, P.; Song, M.; Ju, X. Entrepreneurial orientation and performance: Is innovation speed a missing link? J. Bus. Res. 2016, 69, 683-690. [CrossRef]

56. Teece, D.J.; Leih, S. Uncertainty, innovation and dynamic capabilities. Calif. Manag. Rev. 2016, 58, 5-12. [CrossRef]

57. IEA International Energy Agency. Market Report Series: Renewables 2018. Analysis and Forecasts to 2023; IEA: Paris, France, 2018.

58. Roper, S.; Tapinos, E. Taking risks in the face of uncertainty: An exploratory analysis of green innovation. Technol. Forecast. Soc. Chang. 2016, 112, 357-363. [CrossRef]

59. Chang, Y.; Thomas, H. The impact of diversification strategy on risk-return performance. Acad. Manag. Perspect. 1987, 1, 2-6. [CrossRef]

60. Miller, D.J. Technological diversity, related diversification, and firm performance. Strateg. Manag. J. 2006, 27, 601-619. [CrossRef]

61. Mohr, J.; Sengupta, S.; Slater, S. Marketing of High-Technology Products and Innovations, 3rd ed.; Pearson: Harlow, UK, 2013.

62. Barney, J.B.; Clark, D.N. Resource Based Theory: Creating and Sustaining Competitive Advantage; Oxford University Press: Oxford, UK, 2007.

63. Rasmussen, E.; Mosey, S.; Wright, M. The influence of university departments on the evolution of entrepreneurial competences in spin-off ventures. Res. Policy 2014, 43, 92-106. [CrossRef]

64. Fern, M.J.; Cardinal, L.B.; O'Neill, H.M. The genesis of strategy in new ventures: Escaping the constraints of founder and team knowledge. Strateg. Manag. J. 2011, 33, 427-447. [CrossRef] 
65. Visintin, F.; Pittino, D. Founding team composition and early performance of university—Based spin-off companies. Technovation 2014, 34, 31-43. [CrossRef]

66. Heirman, A.; Clarysse, B. Which tangible and intangible assets matter for innovation speed in start-ups? J. Prod. Innov. Manag. 2007, 24, 303-315. [CrossRef]

67. Mason, C.; Brown, R. Entrepreneurial Ecosystem and Growth-Oriented Entrepreneurship; Background Paper to the OECD-LEED Workshop in The Hague, November 7, 2013; OECD: Paris, France, 2014.

68. Spigel, B. The relational organization of entrepreneurial ecosystems. Entrep. Theory Pract. 2017, 41, 49-72. [CrossRef]

69. Hayter, C.S. A trajectory of early-stage spinoff success: The role of knowledge intermediaries within an entrepreneurial university ecosystem. Small Bus. Econ. 2016, 47, 633-656. [CrossRef]

70. Feld, B. Start-up Communities: Building an Entrepreneurial Ecosystem in Your City; John Wiley: Hoboken, NJ, USA, 2012.

71. Vedula, S.; Kim, P. Gimme shelter or fade away: The impact of regional entrepreneurial ecosystems on venture survival. Ind. Corp. Chang. 2019, 28, 827-854. [CrossRef]

72. Palm, J. Development of sustainable energy systems in Swedish municipalities: A matter of path dependency and power relations. Local Environ. 2006, 11, 445-457. [CrossRef]

73. Amundsen, H.; Hovelsrud, G.K.; Aall, C.; Karlsson, M.; Westskog, H. Local governments as drivers, towards the 1.5 degree ambition. Curr. Opin. Environ. Sustain. 2018, 31, 23-29. [CrossRef]

74. Ansell, C.; Torfing, J. Handbook on Theories of Governance; Edward Elgar Publishing: Cheltenham, UK, 2016.

75. Nabatchi, T.; Sancino, A.; Sicilia, M. Varieties of participation in public services: The who, when, and what of coproduction. Public Adm. Rev. 2017, 77, 766-776. [CrossRef]

76. Michels, A.; De Graaf, L. Examining citizen participation: Local participatory policy-making and democracy revisited. Local Gov. Stud. 2017, 43, 875-881. [CrossRef]

77. Smeds, E.; Acuto, M. Networking cities after Paris: Weighing the ambition of urban climate change experimentation. Glob. Policy 2018, 9, 549-559. [CrossRef]

78. Krog, J. How municipalities act under the new paradigm for energy planning. Sustain. Cities Soc. 2019, 47. [CrossRef]

79. Allison, P. Event History Analysis and Survival Analysis. Sage Series: Quantitative Application in the Social Sciences, 2nd ed.; Sage Publishing: Thousand Oaks, CA, USA, 2014.

80. Everitt, B.; Howell, D. (Eds.) Encyclopedia of Statistics in Behavioral Science; Wiley: Chichester, UK, 2005 ; pp. 568-575.

81. Cox, D.R. Regression models and life tables (with discussion). J. R. Statist. Soc. B 1972, 34, 187-220.

82. Triguero, A.; Moreno-Mondéjar, L.; Davia, M. Drivers of different types of eco-innovation in European SMEs. Ecol. Econ. 2013, 92, 25-33. [CrossRef]

83. Marin, G.; Marzucchi, A.; Zoboli, R. SMEs and barriers to Eco-innovation in the EU: Exploring different firm profiles. J. Evol. Econ. 2015, 25, 671-705. [CrossRef]

84. Meijer, L.; Huijben, J.; Van Boxstael, A.; Romme, A. Barriers and drivers for technology commercialization by SMEs in the Dutch sustainable energy sector. Renew. Sustain. Energy Rev. 2019, 112, 114-126. [CrossRef]

85. Nordic9, MemfoAct secured 16 million NOK. 2010. Available online: http:/ / www.Nordic9.com/news/ (accessed on 20 November 2020).

86. Available online: https://nordic9.com/news/memfoact-secured-nok16m-from-alliance-venture-viking-venture-salvesenthams-and-glr-news5956125588 (accessed on 10 October 2020).

87. Available online: https://business.gov.nl/financing-your-business/funding-and-loans/funding-by-private-investors-or-banks / funding-from-venture-capital-companies / (accessed on 20 November 2020).

88. Van der Weerd, R. Institutional Change Through Local Experimentation. The Case of Electrical Vehicles in the Netherlands. Master's Thesis, Utrecht University, Utrecht, The Netherlands, June 2013.

89. Greencarcongress. Epyon Opens First Commercial Level Fast Charging Station in Europe. 2010. Available online: https: / / www.greencarcongress.com/2010/05/epyon-20100521.html (accessed on 10 October 2020).

90. FlexSol-Solutions. 2020. Available online: http:/ / www.flexsol-solutions.com (accessed on 20 November 2020).

91. Hydro. Elonroad Teams with Hydro to Build Road that Dynamically Charges Electric Vehicles (while Driving). 2020. Available online: https:/ / www.hydro.com/en/media/news/2020/elonroad-teams-with-hydro-to-build-road-that-dynamically-chargeselectric-vehicles (accessed on 20 December 2020).

92. Science Business. NTNU Spin-Out Chapdrive Raises 10 Million Euro for Wind-Turbine Technology. 2010. Available online: https: / / sciencebusiness.net/news / 68241/NTNU-spin-out-Chapdrive-raises-\%26euro\%3B10M-for-wind-turbine-technology (accessed on 20 November 2020).

93. Eriksen Ringheim, T.; Skaret-Thoresen, L. Venture Capital Funds and Clean-Tech Startups. Master's Thesis, Norwegian University of Science and Technology, Trondheim, Norway, 2018.

94. University of Amsterdam UvA. UvA Spin-off Photanol Partners with AkzoNobel. 2014. Available online: https://www.uva.nl/en/ content/news/press-releases/2014/09/uva-spin-off-photanol-partners-with-akzonobel.html (accessed on 15 September 2020).

95. The Hague-Impact City, Start-up in Residence. The Hague Program. 2019. Available online: www.starthups.co (accessed on 15 October 2020).

96. PV Magazine. Sweden Plans 60\% Subsidy for Residential Battery. 2016. Available online: https://www.pv-magazine.com/2016 /11/23/sweden-plans-60-subsidy-for-residential-batteries_100026993/\#ixzz4Qq7EFdlv (accessed on 15 November 2020). 
97. STING. 2020. Available online: https:/ / sting.co/en (accessed on 30 November 2020).

98. Diaz-Peréz, C.; Wixted, B.; Holbrook, J.A. Vancouver's fuel cell cluster: New opportunities or a genteel decline? In Cities and Sustainable Technology Transitions. Leadership, Innovation and Adoption; Van Geenhuizen, M., Holbrook, J.A., Taheri, M., Eds.; Edward Elgar: Cheltenham, UK, 2018; pp. 136-163.

99. Dahl Andersen, A.; Bugge, M.; Capasso, M.; Jolly, S.; Klitkou, A.; Sotarauta, M.; Markku, S.; Suvinen, N. Green Growth in Nordic Regions; Nordic Institute for Studies in Innovation, Research and Education, and Nordforsk: Oslo, Norway, 2019.

100. Kern, K. Cities as leaders in EU multilevel climate governance: Embedded upscaling of local experiments in Europe. Environ. Politics 2019, 28, 125-145. [CrossRef]

101. Hoppe, T.; Miedema, M. A governance approach to regional energy transition: Meaning, conceptualization and practice. Sustainability 2020, 12, 915. [CrossRef]

102. SNN Consortium North-Netherlands. EU Support for the Green Hydrogen Region of Europe. 2020. Available online: https: / / www.snn.nl/en/eu-support-for-the-green-hydrogen-regions-of-Europe-Northern-Netherlands (accessed on 27 November 2020).

103. Taheri, M.; Van Geenhuizen, M. Teams' boundary-spanning capacity at university: Performance of technology projects in commercialization. Technol. Forecast. Soc. Chang. 2016, 111, 31-43. [CrossRef]

104. Champenois, C.; Etzkowitz, H. From boundary line to boundary space: The creation of hybrid organizations as a Triple Helix micro-foundation. Technovation 2018, 76, 28-39. [CrossRef]

105. Leydesdorff, L.; Deakin, M. The triple-helix model of smart cities: A neo-evolutionary perspective. J. Urban Technol. 2011, 18, 53-63. [CrossRef]

106. Goddard, J.; Vallance, P. The Civic University and the Leadership of Place; University of Newcastle: Newcastle, UK, 2012.

107. Lennon, B.; Dunphy, N.P.; Sanvicente, E. Community acceptability and the energy transition: A citizens' perspective. Energy Sustain. Soc. 2019, 9,1-18. [CrossRef]

108. Li, F.G.; Pye, S. Uncertainty, politics, and technology: Expert perceptions on energy transitions in the United Kingdom. Energy Res. Soc. Sci. 2018, 37, 122-132. [CrossRef]

109. Jansen, M.; Van der Voort, H. Adaptive governance: Towards a stable, accountable and responsive government. Gov. Inf. Q. 2016, 33, 1-5. [CrossRef]

110. Sharma-Wallace, L.; Velarde, S.J.; Wreford, A. Adaptive governance good practice: Show me the evidence! J. Environ. Manag. 2018, 222, 174-184. [CrossRef] [PubMed]

111. Haasnoot, M.; Kwakkel, J.H.; Walker, W.E.; ter Maat, J. Dynamic adaptive policy pathways: A method for crafting robust decisions for a deeply uncertain world. Glob. Environ. Chang. 2013, 23, 485-498. [CrossRef]

112. Kwakkel, J.H.; Haasnoot, M.; Walker, W.E. Developing dynamic adaptive policy pathways: A computer-assisted approach for developing adaptive strategies for a deeply uncertain world. Clim. Chang. 2014, 132, 373-386. [CrossRef]

113. D'Este, P.; Patel, P. University-industry linkages in the UK: What are the factors underlying the variety of interactions with industry? Res. Policy 2007, 36, 1295-1313. [CrossRef]

114. Balest, J.; Secco, L.; Pisani, E.; Caregnani, G. Municipal Transition: The social, energy and spatial dynamics of socio-technical change in South Tyrol, Italy. Energy Res. Soc. Sci. 2019, 54, 211-223. [CrossRef]

115. C40 Cities Climate Leadership Group. Available online: https://www.c40.org (accessed on 3 February 2021).

116. EnergyCities, the European Association of Cities in Energy Transition. Available online: https://www.energy-cities.eu (accessed on 3 February 2021).

117. Villamor, E.; Akizu-Gardoki, O.; Azurza, O.; Urkidi, L.; Campos-Celador, A.; Basurko, I.; Hinojal, I.B. European cities in the energy transition: A preliminary analysis of 27 cities. Energies 2020, 13, 1315. [CrossRef] 